\title{
Oligosaccharide Synthesis Using Fluorous-Tag Method
}

\author{
フルオラス・タグ法による糖鎖合成
}

\author{
Miura, Tsuyoshi \\ The Noguchi Institute, 1-8-1 Kaga, Itabashi-ku, Tokyo 173-0003, Japan \\ FAX: 81-3-5944-3214, E-mail: t-miura@ noguchi.or.jp
}

Key Words: fluorous, tag, protective group, oligosaccharide, synthesis

\begin{abstract}
The fluorous-tag method is a methodology which could purify product by partitioning the product mixture between a fluorous solvent such as perfluorohexane and an organic solvent, and is an excellent strategic alternative to solid-phase synthesis. In this report, the fluorous-tag method is initially described. The possibility of oligosaccharide synthesis using fluorous-tag method is then discussed.
\end{abstract}

要 約

フルオラス・タグ法はフルオラス溶媒 (ペルフルオロヘキサ ンなど) と有機溶媒との分液抽出操作で生成物を精製できる方法 論であり、固相合成法の優れた代替法として注目を集めてい る。本稿ではまず初めにフルオラス・タグ法の特徵について論 じる。次に、フルオラス・タグ法の糖鎖合成への応用の可能性 について議論する。

\section{A. Introduction}

The oligosaccharides on cell surfaces play an important role in biological processes such as cell-cell interaction, cell adhesion, and immunogenic recognition (1). However, the synthesis of an oligosaccharide is not easy. There is no automatic synthesizer of an oligosaccharide commercially available. Solidphase synthesis of oligosaccharides has been actively studied, because peptides and nucleotides are easily prepared by solidphase synthesis using a commercially available automatic synthesizer. However, the usual solid-phase method suffers from some serious disadvantages, such as reduced reactivity, the difficulty of large-scale synthesis, and the inability to monitor the reaction. The improved solid-phase method overcomes some of the disadvantages of traditional solid-phase methods (2). Recently, there has been greater emphasis on fluorous chemistry. In this report, the possibility of oligosaccharide synthesis by the fluorous-tag method applying fluorous chemistry is described.

\section{B. Birth of Fluorous Chemistry}

A fluorous solvent such as perfluorohexane $\left(\mathrm{FC}-72^{\mathrm{TM}}\right)$ and perfluoromethylcyclohexane $\left(c-\mathrm{C}_{6} \mathrm{~F}_{11} \mathrm{CF}_{3}\right)$ is insoluble in most organic solvents and in water. A highly fluorinated compound is extracted with fluorous solvents, and is readily separated from nonfluorinated compounds through simple fluorous-organic solvent partitioning. Horváth et al. used these properties to report for the first time the fluorous biphase system (FBS) in 1994. As shown in Scheme 1, a mixture of toluene and $c-\mathrm{C}_{6} \mathrm{~F}_{11} \mathrm{CF}_{3}$ form two layers. A catalyst containing the perfluorochain is soluble in

\section{A. はじめに}

細胞表層の糖鎖は細胞間相互作用、細胞接着、免疫応答な どの生物学的過程において重要な役割を果たしている(1)。しか し、糖鎖の合成は容易ではなく、自動合成装置は未だ市販され るに至っていない。ペプチドや核酸の合成には固相法による自 動合成装置がすでに市販されているため、固相法による糖鎖合 成研究は現在活発に行われている。しかし、固相合成法は反応 をリアルタイムでモニターできない、反応性が低下する、大量 合成に向かないといった深刻な問題点を抱えている。これらの 問題点を解決すべく、いくつかの優れた改良固相合成法が報告 された(2)。そんな中、近年フルオラス化学という分野が注目を 集めており、フルオラス化学をさらに応用したフルオラス・夕 グ法は固相合成法の優れた代替法として期待されている。本稿 ではフルオラス・タグ法による糖鎖合成の可能性について議論 したい。

\section{B. フルオラスケミストリーの誕生}

ペルフルオロヘキサン $\left(\mathrm{FC}-72^{\mathrm{TM}}\right)$ やペルフルオロメチルシク ロヘキサン $\left(c-\mathrm{C}_{6} \mathrm{~F}_{11} \mathrm{CF}_{3}\right)$ などのフルオラス (親フルオロカーボン 性の) 溶媒はほとんどの有機溶媒拉よび水とは混ざらない。フッ 素含量の高い有機化合物はフルオラス溶媒と有機溶媒との分液 操作によって選択的にフルオラス溶媒に抽出され、通常の有機 化合物から容易に分離精製することができる。1994 年に Horváth らが初めてこの性質を利用した Fluorous Biphase System (FBS) を 報告した (3)。スキーム 1 に示すように、トルエンと $c-\mathrm{C}_{6} \mathrm{~F}_{11} \mathrm{CF}_{3}$ 


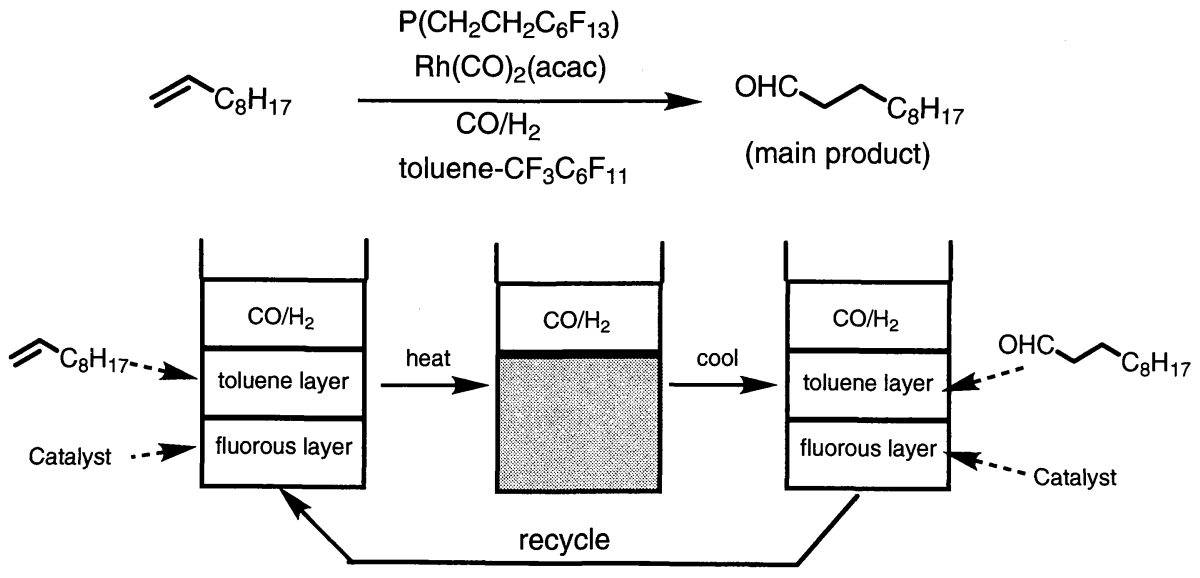

Scheme 1. Fluorous biphase system (FBS).

the fluorous $\left(c-\mathrm{C}_{6} \mathrm{~F}_{11} \mathrm{CF}_{3}\right)$ layer, and the olefin as the substrate is soluble in toluene. Toluene is soluble in $c-\mathrm{C}_{6} \mathrm{~F}_{11} \mathrm{CF}_{3}$ by heating under a hydrogen and carbon monoxide atmosphere, and the reaction proceeds. The reaction mixture forms two layers again by cooling to room temperature to give the aldehyde, which can be extracted with toluene. The fluorous catalyst can be extracted with $c-\mathrm{C}_{6} \mathrm{~F}_{11} \mathrm{CF}_{3}$ and is recyclable. FBS is an excellent method, which can easily separate an expensive catalyst and product.

\section{Fluorous-Tag Method (Fluorous Synthesis)}

Curran et al. reported a fluorous synthesis using the fluorous-tag in 1997. The concept of fluorous synthesis is shown in Scheme 2. The substrate, which had the fluorous-tag, exhibits a high solubility for the fluorous solvent. After liquid-phase synthesis for the fluorous substrate, the reaction mixture is partitioned between the fluorous and organic solvents, such that the excess reagent and the product containing the fluorous-tag are extracted into the organic phase and the fluorous phase, respec-
は室温で二層を形成し、ペルフルオロ鎖で修飾された触媒はフ ルオラス $\left(c-\mathrm{C}_{6} \mathrm{~F}_{11} \mathrm{CF}_{3}\right)$ 層に、基質のオレフィンはトルエン層に 溶け込む。水素と一酸化炭素の雲囲気下加熱すると、トルエン と $c-\mathrm{C}_{6} \mathrm{~F}_{11} \mathrm{CF}_{3}$ は混ざり合い均一層となり、反応が進行する。反 応液を室温に戻すと再び二層を形成し、トルエン層からは生成 物のアルデヒドが得られる。 $c-\mathrm{C}_{6} \mathrm{~F}_{11} \mathrm{CF}_{3}$ 層からは触媒が回収、再 利用される。以上のように、FBS は高価な触媒と生成物を容易 に分離精製できる優れた方法論である。

C. フルオラス・タグ法 (フルオラス合成法)

1997 年、Curran らによってフルオラス・タグを利用したフ ルオラス合成法が報告された (4)。スキーム 2 に示すフルオラ ス合成法の概念について説明する。基質にフルオラス・タグを 導入するとフルオラス溶媒への溶解性が向上する。この基質に 対して通常の液相合成反応を行い、後処理として有機溶媒とフ ルオラス溶媒との液-液分配抽出を行う。有機層からは過剩に用 いた試薬等が分配除去され、フルオラス・タグの付いた生成物 はフルオラス層に抽出される。以上の操作を繰り返し、望みの

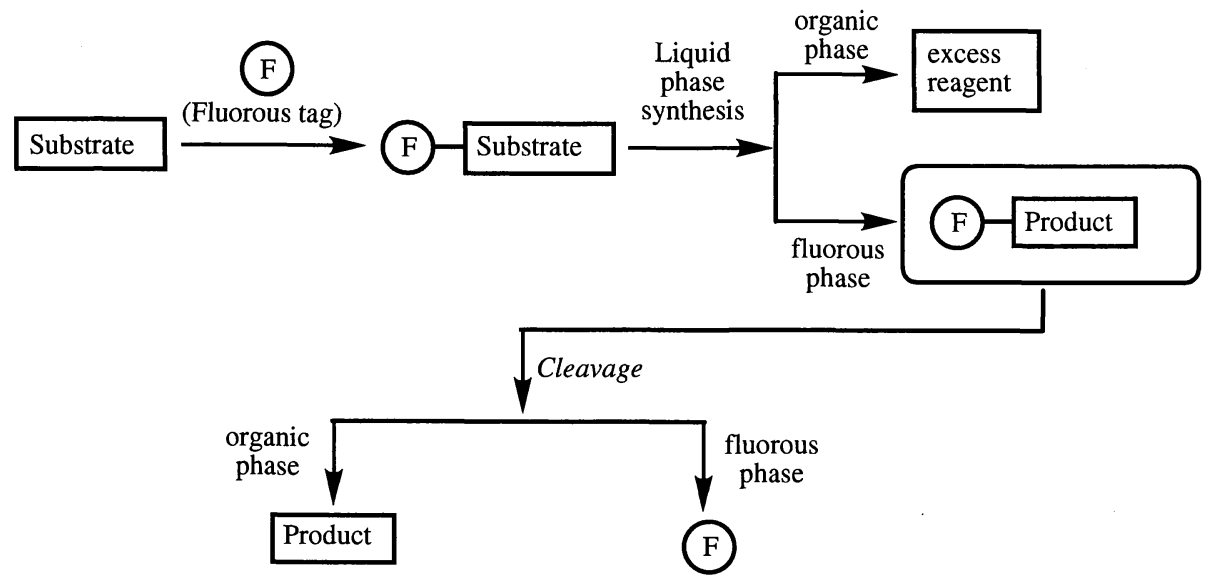

Scheme 2. Fluorous synthesis using fluorous-tag. 
tively. The desired chemical structure is assembled by repetition of the above procedure. Finally, the fluorous-tag is removed to give the desired product, which can be extracted with an organic solvent. The fluorous-tag can be extracted with a fluorous solvent and is recyclable. Fluorous synthesis is an efficient synthetic method without the need for column chromatography, and is comparable to solid-phase synthesis.

\section{Fluorous Protecting Groups}

The fluorous protecting groups, which can be easily introduced and removed, are essential for the fluorous synthesis performance. As shown in Figure 1, several protecting groups have already been reported. Silyl ether-type fluorous protecting groups (A (5), B (6)), acetal-type (C (7), D (8)), and benzyl ether-type (E (9)) for the hydroxyl function have been reported. The tert-butyl ester-type fluorous protecting group (F (10)) for carboxyl function has been reported. The Boc-type (G (11)) and Cbz-type (H (12), I (13)) for the amino function have been reported. Each fluorous protecting group involves one, two, or three perfluorochains.

\section{E. Synthesis of Disaccharide Using Benzyl Ether-Type Fluorous Protecting Group}

Curran et al. reported the synthesis of a disaccharide using the benzyl ether-type fluorous protecting group (E, Bnf) in 1998 (9). The fluorous protecting group, Bnf, was introduced to three hydroxyl functions of glycal 1 to afford compound $\mathbf{2}$ as a glycosyl donor. Compound $\mathbf{2}$ coupled with an excess amount of the glycosyl acceptor 3 to give the disaccharide derivative 4 . The reaction mixture was partitioned between methanol and FC-72, such that the fluorous disaccharide and the excess glycosyl acceptor 3 were extracted into FC-72 and methanol, respectively. The Bnf group of $\mathbf{4}$ was easily removed by hydrogenation to afford the deprotected disaccharide derivative 5 , which was extracted with methanol by partitioning the
化学構造を構築した後にフルオラス・タグを切断する。そし て、有機溶媒とフルオラス溶媒とで分配抽出すると、有機層か らは目的の生成物が得られ、フルオラス層からはフルオラス。 タグが回収再利用される。以上のフルオラス合成法はカラムク ロマトグラフィーなどの精製操作を省ける効率的な合成法であ り、固相合成法に匹敵しうる方法論である。

\section{D. フルオラス保護基}

フルオラス合成法を行うにあたり、導入・除去容易な保護基 として利用できるフルオラス・タグは必要不可欠である。図1に 示すように、いくつかのフルオラス保護基が報告されている。

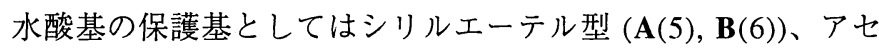

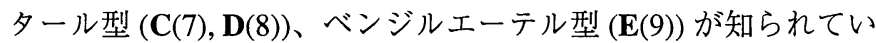
る。また、カルボキシル基の保護基としては tert-ブチルエステ ル型 $(\mathbf{F}(10))$ が、アミノ基の保護基としては Boc 型 $(\mathbf{G}(11))$ と Cbz 型 (H(12), I(13)) が報告されている。いずれの保護基も 1 から 3 本のペルフルオロ鎖を有するものである。

\section{E. ベンジルエーテル型フルオラス保護基を用いた二糖合成}

Curran らは 1998 年にベンジルエーテル型フルオラス保護基 (E, Bnf) を用いた二糖合成を報告した (9)。彼らはBnfをグリカー ル 1 の三つの水酸基に導入した化合物 2 を糖供与体として用い、 過㮃の糖受容体 3 と反応させて二糖誘導体 4 を合成した。反応 後のメタノールと FC-72 との分配抽出によって、FC-72 層から 二糖誘導体 4 を、メタノール層からは過剩に用いた糖受容体 3 を回収している。二糖誘導体 4 の Bnf 基は接触還元により除去 でき、反応後の FC-72 との分配抽出によって、メタノール層か<smiles>[R6]C1OCCCC1CC(F)F</smiles>

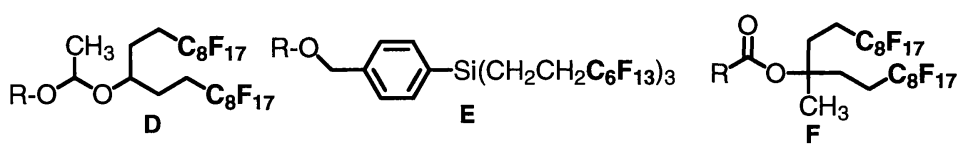

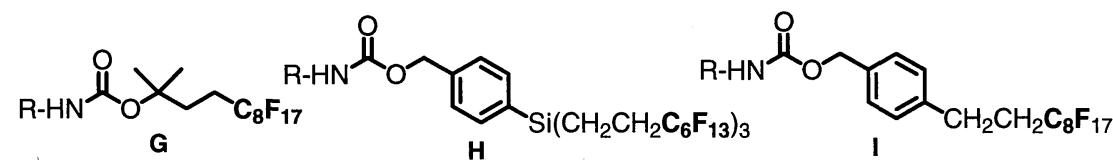

Fig. 1. Example of fluorous protecting groups. 


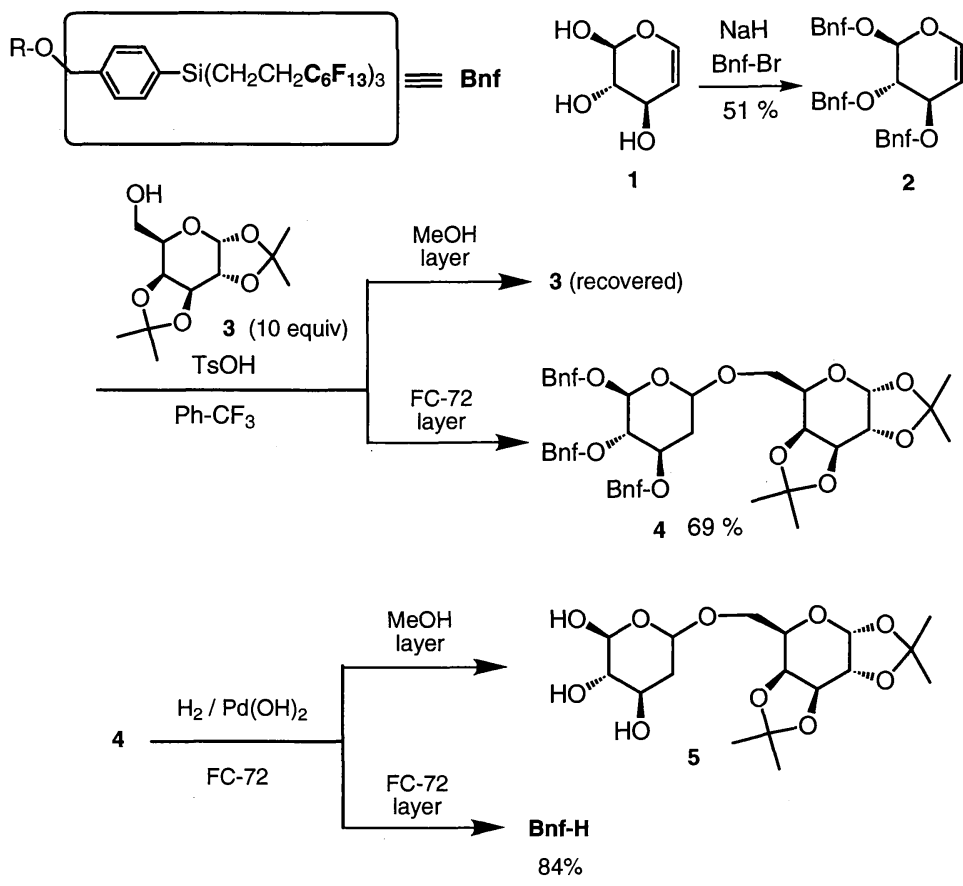

Scheme 3. Fluorous disaccharide synthesis.

mixture between methanol and FC-72. The reduced fluorous tag (Bnf-H) was obtained from the FC-72 layer. This report is the first example of applying the fluorous-tag method to oligosaccharide synthesis. However, the fluorous disaccharide synthesis suffers from some disadvantages. The yield for the reaction step to introduce the Bnf group to the hydroxyl function was not satisfactory. Their method is limited to disaccharide synthesis because the Bnf group was introduced to the glycosyl donor. In addition, only the unnatural type of 2-deoxy disaccharide was prepared due to glycosylation by a glycal method.

\section{F. Oligosaccharide Synthesis Using the Fluorous Acyl Pro- tecting Group}

The authors have developed a fluorous acyl protecting group, which has not yet been reported, and applied it to a more practical oligosaccharide synthesis using the fluorous-tag method (14). The fluorous protecting group, Bfp, could be easily prepared on a large scale. The Bfp group was readily introduced and removed to the carbohydrate hydroxyl functions in high yield. We introduced the fluorous-tag Bfp to the glycosyl acceptor but not to the glycosyl donor, and could efficiently synthesize the longer chain oligosaccharide. As shown in Scheme 4, the Bfp group was introduced to the hydroxyl functions of 6 . After removal of the triphenylmethyl group, the fluorous glycosyl acceptor $\mathbf{8}$ was coupled with the glycosyl donor 9 using the trichloroimidate glycosylation method to give the fluorous disaccharide 10. After removal of the TBDPS group from 10 by treatment with HF-Py, a repeat of the glycosylation afforded the
らは脱保護された二糖誘導体 $\mathbf{5}$ が、FC-72 層から還元されたフ ルオラス・タグ Bnf-H がそれぞれ得られた。フルオラス・タグ 法を糖鎖合成に応用した初めての報告例である。しかし、Bnfの 導入収率が低いこと、糖供与体にBnf を導入しているために二 糖合成に限定されること、グリカール法によるグリコシル化の ために非天然型の 2-デオキシ体しか合成できないといった問題 点が残された。

\section{F. アシル型フルオラス保護基を用いた糖鎖合成}

著者らは保護基として報告例の無かったアシル型のフルオ ラス保護基 Bfp を開発することによって、フルオラス・タグ法 のより実践的な糖鎖合成への応用に展開した (14)。フルオラス 保護基 Bfp は容易に大量調製でき、糖水酸基へ高収率で導入、 除去できる。 Bfp 基を糖供与体ではなく糖受容体の水酸基に導 入し、長鎖の天然型糖鎖を効率的に合成することを可能とし た。スキーム 4 に示すように、Bfp 基を化合物 6 の水酸基に導 入し、続いてトリチル基を除去した後、糖供与体 9 とのトリク ロロイミデート法によるグリコシル化反応によって二糖誘導体 10 を得た。化合物 10 の TBDPS 基を HF-Py 処理によって除去 し、さらにグリコシル化反応を繰り返して四糖誘導体 12 の合 成に成功した。各合成中間体は有機溶媒と FC-72 との分配抽出 

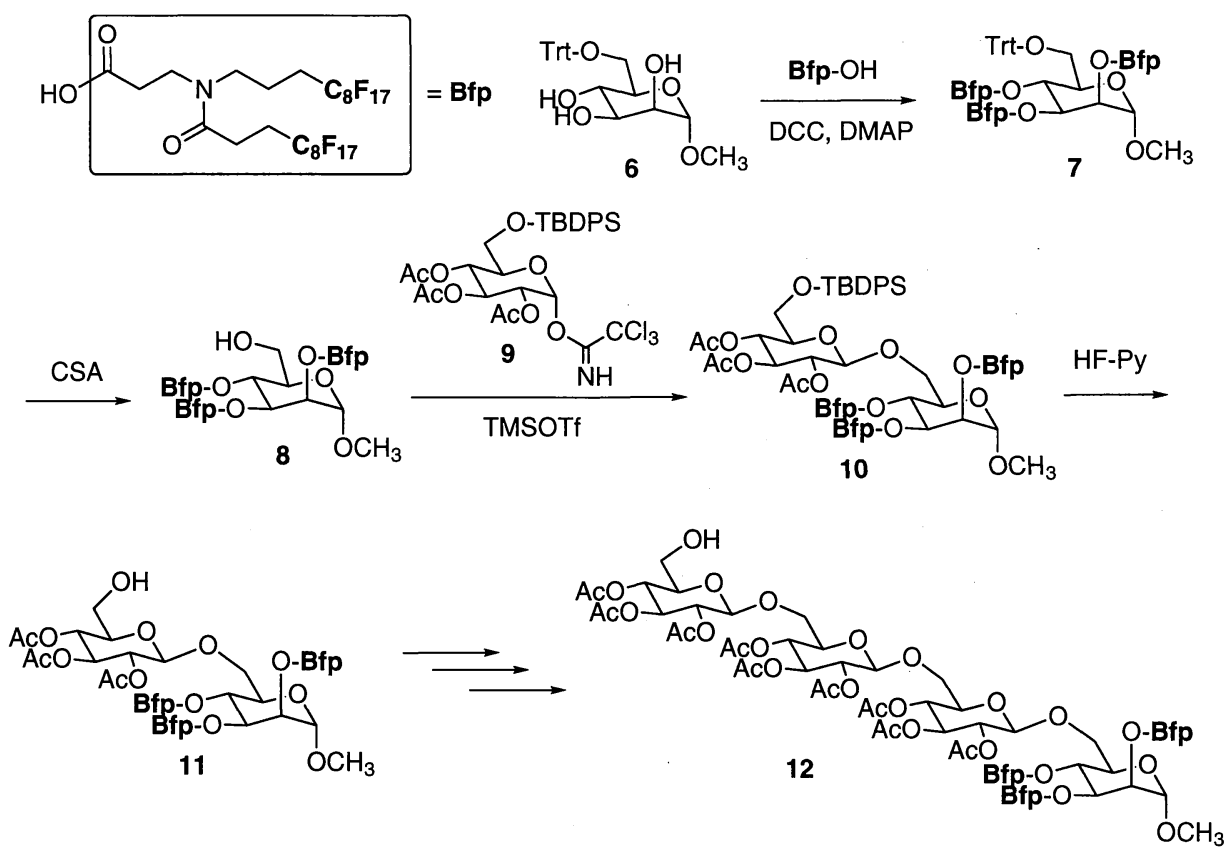

Scheme 4. Fluorous oligosaccharide synthesis using fluorous protective group Bfp.

fluorous tetrasaccharide 12. Each fluorous intermediate was easily purified by partitioning the product mixture between FC72 and an organic solvent. No further purification such as silicagel column chromatography was carried out. Therefore, the use of the Bfp group made it possible to rapidly synthesize an oligosaccharide.

The derivative $\mathbf{1 7}$ of the Gb3 oligosaccharide, which was recognized by vero-toxin, was also rapidly synthesized using the fluorous protective group, Bfp (15). As shown in Scheme 5, the introduction of the Bfp group to the four hydroxyl functions of the lactose derivative $\mathbf{1 3}$, followed by removal of the benzylidene and triphenylmethyl groups and the selective benzoylation of the primary hydroxyl functions afforded the
操作により容易に精製できるため、カラムクロマトグラフィー などの精製操作を省略でき、迅速に糖鎖を合成することを可能 とした。

また、フルオラス保護基 Bfp を用いることにより、ベロ毒 素が認識することで知られる Gb3 糖鎖の誘導体 17 を迅速に合 成することにも成功した $(15)$ 。スキーム 5 に示すように、ラク トース誘導体 13 の 4 つの水酸基にBfp を導入し、続くベンジ リデン基とトリチル基の除去、 1 級水酸基選択的ベンゾイル化 により糖受容体 15 を得た。そして、糖供与体 16 とのグリコシ ル化、 $\mathrm{NaOMe}$ 処理による $\mathbf{B f p}$ 基の除去によって Gb3 糖鎖誘導

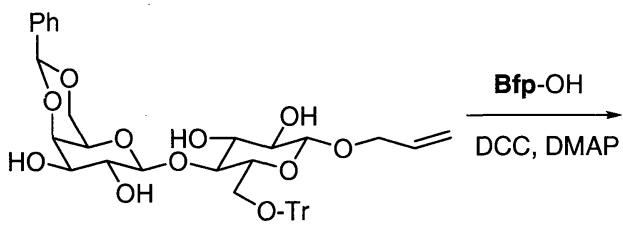

13

$\mathrm{BnO} \mathrm{OBn}$

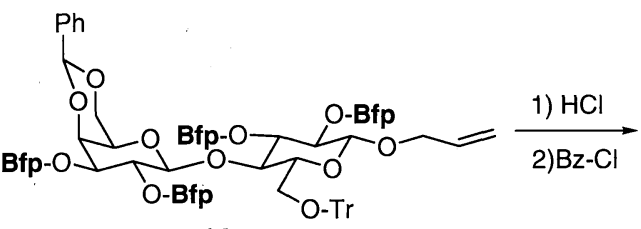

14

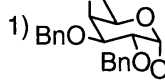

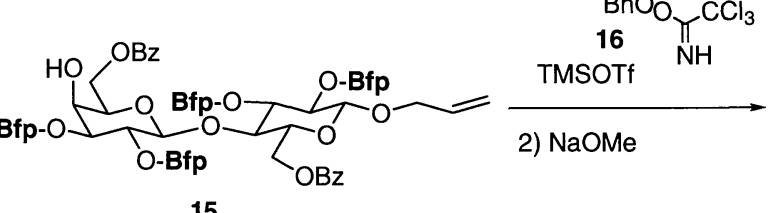

15

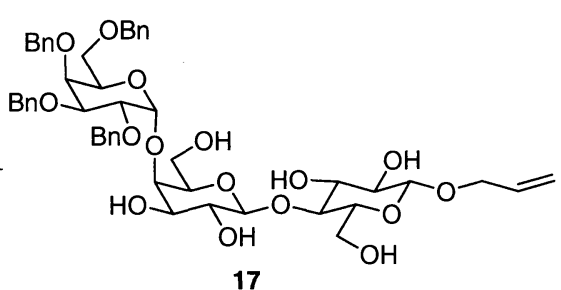

Scheme 5. Synthesis of Gb3 oligosaccharide derivative using fluorous protective group Bfp. 
fluorous glycosyl acceptor $\mathbf{1 5}$. The glycosylation of $\mathbf{1 5}$ with the glycosyl donor 16, followed by removal of the Bfp groups by treatment with $\mathrm{NaOMe}$ gave the $\mathrm{Gb} 3$ oligosaccharide derivative 17 in $34 \%$ overall yield from 13 (5 steps). Each fluorous intermediate was easily purified by partitioning the product mixture between FC-72 and an organic solvent. The pure Gb3 oligosaccharide derivative 17 was obtained by purification using silica-gel column chromatography only in the final step.

\section{G. Oligosaccharide Synthesis on a Fluorous Support}

The authors reported the oligosaccharide synthesis using the fluorous tag $\mathrm{Hfb}$ containing six perfluorooctyl chains (16). The attachment of the fluorous-tag Hfb through just the anomeric hydroxyl functionality of the glycosyl acceptor allowed an efficient oligosaccharide synthesis because the fluorine content in $\mathrm{Hfb}$ is very high. We named the fluorous-tag $\mathrm{Hfb}$, the fluorous support. As shown in Scheme 6, the Hfb group was introduced to the anomeric hydroxyl function of compound $\mathbf{1 8}$ to afford the fluorous glycosyl acceptor 19. A repeat of the selective deprotection and the glycosylation produced the trisaccharide derivative 20. Each fluorous intermediate was easily purified by partitioning the product mixture between FC-72 and an organic solvent. The Hfb group of $\mathbf{2 0}$ was removed by treatment of $\mathrm{NaOMe}$ in the final step to give the trisaccharide $\mathbf{2 1}$ in
体 17 を全工程 ( 5 工程) 収率 34\% で合成した。各合成中間体は 有機溶媒と FC-72 との分配抽出操作により精製し、最終段階の みシリカゲルカラムで精製し、高純度の $\mathrm{Gb} 3$ 糖鎖誘導体 17 を 得た。

\section{G. フルオラス担体を用いた糖鎖合成}

著者らは 6 本のペルフルオロオクチル鎖を有するフルオラ ス・タグ Hfb を用いた糖鎖合成についても報告した (16)。フル オラス・タグ Hfb のフッ素含量は非常に高いため、糖受容体の アノマー水酸基 1 籄所に Hfb を導入するだけで、効率的な糖鎖 合成が可能となる。フルオラス・タグ Hfb は保護基と言うより はむしろ、固相合成担体に匹敵しうるフルオラス担体と言え る。スキーム 6 に示すように、化合物 18 のアノマー水酸基に Hfb を導入し、これを糖受容体として用いて、選択的脱保護と グリコシル化反応を繰り返し、三糖誘導体 20 を得た。各合成 中間体は有機溶媒と FC-72 との分配抽出操作により容易に精製 できた。最終工程で $\mathrm{NaOMe}$ 処理することによって Hfb 基を除 去し、最終生成物のみシリカゲルカラムで精製し、全工程 (6工
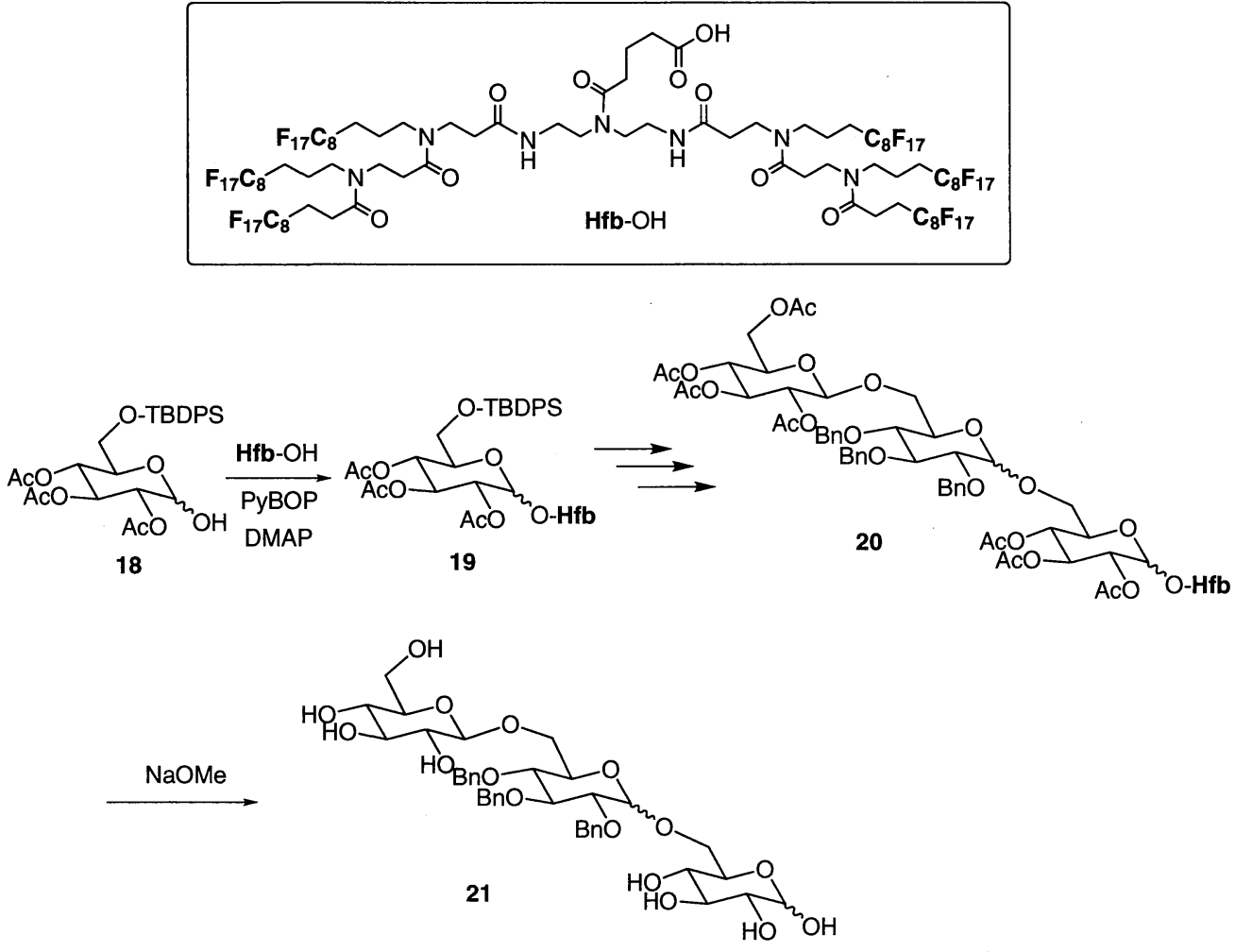

Scheme 6. Oligosaccharide synthesis on fluorous support Hfb. 
Trends in Glycoscience and Glycotechnology Vol.15 No.86 (November 2003) pp.351-358

42\% overall yield from $\mathbf{1 8}$ (6 steps). The pure trisaccharide $\mathbf{2 1}$ was obtained from a single silica-gel column chromatographic purification in the final step. The fluorous support $\mathrm{Hfb}$ can be applied to not only oligosaccharide synthesis but also peptide synthesis (17).

\section{H. Future Direction}

The multi-step synthesis using a fluorous-tag does not need to purify each fluorous synthetic intermediate by silica-gel column chromatography. The fluorous intermediates were purified by partitioning the product mixture between the fluorous and organic solvents. Therefore, the target compounds could be rapidly synthesized. The fluorous compounds could be analyzed by TLC, NMR, and MS, because they are soluble in an organic solvent. The fluorous intermediates could also be subjected to silica-gel column chromatography, if necessary. The reaction could be immediately monitored by TLC, in contrast to the usual solid-phase synthesis. The reaction conditions for each synthetic step could be rapidly optimized. The fluorous synthesis should be applicable to large-scale synthesis and a high reactivity is expected, as it is performed in the liquid phase. Thus, the fluorous synthesis using a fluorous-tag is an excellent strategic alternative to solid-phase synthesis. In the future, I would expect application of the fluorous-tag method to the synthesis of more complex bioactive oligosacchaides by the development of a highly efficient fluorous-tag.
程) 収率 $42 \%$ で三糖誘導体 21 を得た。なお、フルオラス担体 Hfb は糖鎖合成だけでなく、ペプチドの合成にも応用可能であ る (17)。

H. 終わりに

フルオラス・タグを用いた多段階合成では各合成中間体を シリカゲルカラムクロマトグラフィーなどによって精製する必 要がなく、フルオラス溶媒と有機溶媒との分液操作で精製でき るので、迅速に目的化合物を合成できる。また、フルオラス化 合物は通常の有機溶媒にも可溶なために、TLC、NMR、マスス ペクトルによる解析も可能であり、必要に応じてシリカゲルカ ラムによって精製することもできる。通常の固相合成法とは対 照的に、反応を TLCによりリアルタイムでモニターでき、反応 条件の最適化も迅速に行える。フルオラス合成法は液相反応で あるため、高い反応性と大量合成への応用も期待できる。以上 のことから、フルオラス・タグを用いたフルオラス合成法は固 相合成法の問題点のいくつかを補う優れた代替法と言える。今 後、より高性能なフルオラス・タグの出現によって、複雑な生 理活性糖鎖の合成にこのフルオラス・タグ法が応用、発展され ることを期待したい。

\section{References}

1. (a) Varki A. (1993) Glycobiology 3, 97-130; (b) Dwek, R. A. (1996) Chem. Rev. 96, 683-720; (c) Blithe, D. L. (1993) Trends Glycosci. Glycotech. 5, 81-98

2. (a) Manabe, S.; Ito, Y. (2002) J. Am. Chem. Soc. 124, 12638-12639; (b) Kanemitsu, T.; Wong, C.-H.; Kanie, O. (2002) J. Am. Chem. Soc. 124, 3591-3599; (c) Ando, H.; Manabe, S.; Nakahara,Y.; Ito, Y. (2001) J. Am. Chem. Soc. 123, 3848-3849; (d) Eichler, E.; Yan, F.; Sealy, J.; Whitfield, D. M. (2001) Tetrahedron 57, 6679-6693; (e) Ito, Y.; Kanie, O.; Ogawa, T. (1996) Angew. Chem. Int. Ed. Engl. 35, 2510-2512

3. Horváth, I. T.; Rábai, J. (1994) Science, 266, 72-75

4. (a) Studer, A.; Hadida, S.; Ferritto, R.; Kim, S.; Jeger, P.; Wipf, P.; Curran, D. P. (1997) Science, 275, 823-826; (b) Zhang, Q.; Luo, Z.; Curran, D. P. (2000) J. Org. Chem. 65, 8866-8873; (c) Curran, D. P. (2000) Pure Appl. Chem. 72, 1649-1653; (d) Curran, D. P. (1998) Angew. Chem. Int. Ed. 37, 1174-1196

5. Studer, A.; Curran, D. P. (1997) Tetrahedron 53, 6681-6696

6. Röver, S.; Wipf, P. (1999) Tetrahedron Lett. 40, 5667-5670

7. Wipf, P.; Reeves, J. T. (1999) Tetrahedron Lett. 40, 4649-4652

8. (a) Wipf, P.; Reeves, J. T.; Balachandran, R.; Giuliano, K. A.; Hamel, E.; Day, B. W. J. (2000) Am. Chem. Soc. 122, 9391-9395; (b) Wipf, P.; Reeves, J. T. (1999) Tetrahedron Lett. 40, 5139-5142

9. Curran, D. P.; Ferritto, R.; Hua, Y. (1998) Tetrahedron Lett. 39, 4937-4940

10. Pardo, J.; Cobas, A.; Guitlán, E.; Castedo, L. (2001) Org. Lett. 3, 3711-3714

11. Luo, Z.; Williams, J.; Read, R. W.; Curran, D. P. (2001) J. Org. Chem. 66, 4261-4266

12. Schwinn, D.; Bannwarth, W. (2002) Helv. Chim. Acta 85, 255-264

13. (a) Curran, D. P.; Amatore, M.; Guthrie, D.; Campbell, M.; Go, E.; Luo, Z. (2003) J. Org. Chem. 68, 4643-4647; (b) Filippov, D. V.; Zoelen, D. J.; Oldfield, S. P.; Marel, G. A.; Overkleeft, H. S.; Drijfhout, J. W.; Boom, J. H. (2002) Tetrahedron Lett. 43, 7809-7812

14. Miura, T.; Hirose, Y.; Ohmae, M.; Inazu, T. (2001) Org. Lett. 3, 3947-3950

15. Miura, T.; Inazu, T. (2003) Tetrahedron Lett. 44, 1819-1821

16. Miura, T.; Goto, K.; Hosaka, D.; Inazu, T. (2003) Angew. Chem. Int. Ed. 42, 2047-2051

17. Mizuno, M.; Goto, K.; Miura, T.; Hosaka, D.; Inazu, T. (2003) Chem. Commun. 972-973 


\section{Profile of the Author}

Tsuyoshi Miura has been a research scientist at the Noguchi Institute (Tokyo) since 2000. He obtained his Ph.D. in pharmacy from Gifu Pharmaceutical University in 1995 under the supervision of Professor Yukio Masaki. He had postdoctoral feliowship experience at RIKEN (Frontier Research Program; FRP) under Professor Chi-Huey Wong (1995-1997). He has worked as an Assistant Professor at Showa University under Professor Yoshiteru Ida (1997-2000). He then moved to the group headed by Dr. Toshiyuki Inazu at the Noguchi Institute in 2000. His current research is focused on the development of efficient oligosaccharide synthesis and the medicinal chemistry of glyco-conjugates. 